\title{
Prenatal exposure to DDT in malaria endemic region following indoor residual spraying and in non-malaria coastal regions of South Africa*
}

Kalavati Channa ${ }^{a, b,{ }^{*}}$, Halina B. Röllin ${ }^{c, d, \#}$, Therese H. Nøst ${ }^{a, e}$, Jon $\varnothing$. Odland ${ }^{a}$, Torkjel M. Sandanger ${ }^{\mathrm{a}, \mathrm{e}}$

\footnotetext{
${ }^{a}$ Institute of Community Medicine, University of Tromsø, Tromsø, Norway

${ }^{\mathrm{b}}$ National Health Laboratory Services, $\mathrm{NIOH}$, Johannesburg, South Africa

${ }^{c}$ Medical Research Council, Johannesburg, South Africa

${ }^{d}$ University of Pretoria, Pretoria, South Africa

${ }^{\text {e }}$ Norwegian Institute for Air Research (NILU), Fram Centre, Tromsø, Norway
}

*Part of this work was presented at the $23^{\text {rd }}$ Conference of the International Society for Environmental Epidemiology, ISEE 2011, held in Barcelona, Spain, 13-16 September 2011.

$¥$ Corresponding author: Halina B. Röllin

Medical Research Council, Sunnyside Office Park, Broll Place, 4 Carse O'Gowrie Road, Parktown, 2193, South Africa. Tel.:+27 11274 6064; Fax: +27 116426832 .

E-mail address: hrollin@mrc.ac.za

Postal address: PO Box 87373, Houghton 2041, Johannesburg, South Africa

\section{ABSTRACT}

Exemption was granted by the Stockholm Convention in 2004 for use of DDT by indoor residual spraying (IRS) as a malaria vector control. South Africa endorsed the use of DDT in its Malaria Control Programmes in malaria endemic regions and IRS remains a primary method of controlling malaria transmitting mosquitoes in this country. This study examines the impact of IRS on the levels of DDT and its metabolites in maternal blood of delivering women as a measure of prenatal exposure. 
We report on the concentrations of DDT and its metabolites ( $p, p^{\prime}-\mathrm{DDE}, p, p^{\prime}-\mathrm{DDT}, o, p^{\prime}-\mathrm{DDE}$, $o, p^{\prime}-\mathrm{DDD}, p, p^{\prime}-\mathrm{DDD}$, and $\left.o, p^{\prime}-\mathrm{DDT}\right)$ in maternal plasma of 255 delivering women residing in three sites along Indian Ocean, namely in malaria endemic where IRS takes place, low risk and non-malaria sites.

Concentrations of measured compounds were found to be significantly higher in the malaria endemic site ( $p=0.0001)$ : the geometric mean concentration ( $95 \%$ confidence intervals; $\mathrm{n}=91$ ) for $0, p^{\prime}-\mathrm{DDE}$ was $9 \mathrm{ng} / \mathrm{g}$ lipids (7-10); for $p, p^{\prime}-\mathrm{DDE}, 3840 \mathrm{ng} / \mathrm{g}$ lipids (3008-4902); for o,p'-DDD, $8 \mathrm{ng} / \mathrm{g}$ lipids (6-9); for $p, p^{\prime}-\mathrm{DDD}, 26 \mathrm{ng} / \mathrm{g}$ lipids (20-32); for o,p'DDT, $168 \mathrm{ng} / \mathrm{g}$ lipids (127-221) and for $p, p^{\prime}-D D T, 2194 \mathrm{ng} / \mathrm{g}$ lipids (1706-2823). These compounds were also detected in women residing in other sites but in lower concentrations.

The maternal characteristics, age, IRS, number of children and breastfeeding were significantly associated for both $p, p^{\prime}$-DDE and $p, p^{\prime}$-DDT levels in the malaria area where exposure through IRS is predominant. There was no association between maternal characteristics and DDT levels in the low risk and non-malaria area.

Results presented are of particular value to the policy decision makers and regulatory toxicology organizations as they characterise the extent of controlled exposure to DDT used exclusively for IRS purposes.

Furthermore, findings of this study will form a base for further investigation of foetal exposure to pollutants.

Key words: DDT, Malaria, Indoor Residual Spraying, prenatal exposure

\section{Introduction}

Use of DDT [1,1,1-trichloro-2,2-di(4-chlorophenyl)ethane] for malaria vector control, remains a subject of intense scientific and public debate due to its persistence in the environment, its ability to accumulate in the food chain and travel long distances, its affinity for bioaccumulation but also its potential negative health impacts to animals and humans (AMAP, 2004; Porta et al., 1999). 
Malaria accounts for 247 million annual cases globally and remains the second highest cause of mortality and morbidity on the African continent with $91 \%$ of reported global deaths from malaria occurring in the sub-Saharan Africa region (Jaga and Dharmani, 2003; WHO, 2008).

Available epidemiological data on human health effects of DDT and other pesticides show that they are similar to those found in animals, affecting neurodevelopment, causing endocrine disruptions, as well as producing immune related conditions and asthma (Arndt et al., 1999; Eskenazi et al., 2006; Longnecker et al., 2007; Narita et al., 2007; Sunyer et al., 2005; van Wendel de Joode et al., 2001). Other studies indicate that DDT may be implicated in liver and pancreatic cancer aetiologies (Rogan and Chen, 2005). There is also emerging evidence associating exposure to DDT with leukaemia, lymphoma and testicular cancers (Eskenazi et al., 2009). It has been reported that pre-puberty exposure to DDT increases the risk of developing breast cancer in adulthood (Cohn et al., 2007). A number of studies also showed dose-response relationships between serum concentrations of $p, p$ '-DDT and the prevalence of diabetes (Everett et al., 2007; Lee et al., 2006; Rignell-Hydbom et al., 2007).

The most vulnerable window for toxic impact of environmental pollutants is the embryonic and foetal stages. Therefore, of major concern is the possible impact of exposure to DDT on reproductive health including birth outcomes (Eskenazi et al., 2009; Fernandez et al., 2007). It has been reported that in utero exposure to DDT can negatively affect the neurodevelopment in childhood stage, resulting in behavioural problems, decreased attention span at infancy, retarded psychomotor development and decreased cognitive function (Ribas-Fito et al., 2006; Sagiv et al., 2008; Torres-Sanchez et al., 2007). There is evidence that exposure to DDT in utero may also affect thyroid hormone levels (AlvarezPedrerol et al., 2008; Nagayama et al., 2007; Schell et al., 2008). Inconsistent evidence is emerging that high blood concentration of DDTs may affect height, body mass index and other measures of growth in children (Eskenazi et al., 2009). Furthermore, after birth women pass DDT to their babies via lactation (Bouwman et al., 2006).

Based on past and recent research findings confirming the detrimental effects of DDT exposure on human health, the governments and regulatory agencies banned its use and production. In the year 2004, the Stockholm Convention on Persistent Organic Pollutants (POPs) outlawed the use of 12 industrial organic chemicals including DDT (UNEP, 2005).

However, limited exemption was granted for use of DDT to control malaria vector through indoor residual wall spraying (IRS) in malaria endemic regions only, because of the 
resurgence of malaria in many countries and lack of similarly effective alternatives and methods. It is estimated that about 25 countries including South Africa, are currently using DDT for IRS which remains a primary means of controlling malaria-transmitting mosquitoes (Kapp, 2004).

In South Africa, in 1996, partial replacement of DDT use for IRS with pyrethroids and other compounds considered to be less toxic resulted in the reappearance of severe malaria outbreaks and by the year 2000, almost 65000 cases of malaria were diagnosed and 458 deaths occurred countrywide (Figure 1) (DOH, 2010). After the reintroduction of DDT use for IRS in 2001, reported malaria cases in South Africa began to decrease almost immediately with malaria admissions and deaths decreasing by $89 \%$ and outpatient malaria cases by 85\% (O'Meara et al., 2010). At present, approximately 10\% (5 million) of the South African population is at risk of contracting malaria by residing in malaria endemic areas (Rogan and Chen, 2005).

As expected, the re-introduction of DDT for vector control has again intensified public and scientific debate about its toxicity. Of special concern is the exposure of children in utero and after birth through breastfeeding and through living in a contaminated environment (Bouwman and Kylin, 2009; Ostrea et al., 2009; Sapbamrer et al., 2008).

In response to the paucity of comprehensive data on levels of DDT and its metabolites in populations residing in malaria endemic region where the IRS with DDT programme is ongoing, a study was designed and carried out under the auspices of Norway-South Africa Bilateral Research Collaboration, the South African Medical Research Council, the Norwegian Institute for Air Research and the University of Tromsø, Norway during the summer of 2008.

The main objective of this study was to assess the exposure to DDT as a result of the IRS programme. The study investigated the extent of prenatal exposure to DDT and its metabolites by measuring its concentrations in blood plasma of delivering women residing in three Indian Ocean coastal regions of KwaZulu-Natal Province of South Africa, namely: the malaria endemic region where IRS is actively taking place; low risk malaria region and nonmalaria region.

Data obtained will also inform policy decision makers in South Africa and elsewhere as well as the Stockholm Convention, WHO and other global initiatives involved in elimination of the malaria burden. 


\section{Materials and methods}

\subsection{Study sites and population}

The study took place along the coastal line of the Indian Ocean in the KwaZulu-Natal Province in South Africa. Three sites were selected, namely: malaria endemic where regular IRS is taking place; low risk malaria site and non - malaria site.

The malaria endemic site is situated on the north eastern area of the KwaZulu-Natal Province, on the border of Mozambique. The low risk malaria area is situated about $100 \mathrm{~km}$ south of the endemic malaria site and about $160 \mathrm{~km}$ north of the city of Durban. The non malaria site is situated on the Southern Coast of KwaZulu-Natal (about $300 \mathrm{~km}$ away from low risk and $400 \mathrm{~km}$ away from malaria endemic sites). Figure 2 shows the exact locations of each study site within South Africa. Sample collection took place at all study sites during summer months of 2008.

\subsection{Recruitment of participants and informed consent}

Potential participants were women who presented and were admitted for delivery at the local hospitals in three study sites by a health worker on duty and a trained research assistant. The only exclusion factor was for women who resided less than 10 years in the areas studied. In total 255 participants were studied: 91 subjects resided in malaria endemic region where IRS is taking place, 47 subjects resided in low risk malaria region and 117 Subjects resided in non-malaria region.

Women who volunteered to participate signed an informed consent form and agreed to donate a blood sample before delivery and answer a socioeconomic questionnaire by interview in the language of their choice and allow access to their post-partum records (delivery outcomes and eventual complications). All participants understood that their confidentiality was assured and that overall results would be published to contribute towards national and international data. Study subjects were also informed that if their individual results were found to be of medical concern, they would be informed and referred to an appropriate medical facility for consultation. Participants were also informed that they could withdraw their participation at any time. 


\subsection{Sampling procedure}

From each mother, $10 \mathrm{ml}$ of blood was drawn by venous puncture into EDTA containing Vacutainer tubes before delivery process started. The bloods were centrifuged and the plasma transferred into solvent pre-washed tubes, and immediately frozen at $-20^{\circ} \mathrm{C}$ and stored until shipped frozen on dried ice to the Norwegian Institute for Air Research (NILU) laboratory in the Centre, Troms $\varnothing$, Norway for analyses.

\subsection{Analytical methods}

\subsubsection{Sample preparation}

Plasma samples were extracted using an Oasis ${ }^{\circledR}$ HLB Extraction Cartridge (3cc, 540 mg; Waters Corp., Milford, MA, USA) according to the method by Sandanger et al., (Sandanger et al., 2007). In short, internal standards (C-13 labelled $p, p^{\prime}-$ DDE and $p, p^{\prime}-$ DDT), formic acid $(2 \mathrm{ml})$ and water $(2 \mathrm{ml})$ were added to the plasma samples $(2 \mathrm{ml})$, vortexed and left overnight in a refrigerator. The HLB column was conditioned with methanol $(3 \mathrm{ml})$, dichloromethane $(3 \mathrm{ml})$, methanol $(3 \mathrm{ml})$, followed by $5 \%$ methanol in $0.1 \mathrm{M}$ hydrochloric acid ( $3 \mathrm{ml}$ ). The samples were added to the column and dried with $\mathrm{N}_{2}$ and extracted using dichloromethane $(14 \mathrm{ml})$. Following evaporation, the samples were re-suspended in hexane. The extracts were subsequently eluted through a column containing $1 \mathrm{~g}$ deactivated silica (0,063-0,2 mm; Merck, Darmstadt, Germany) and eluted with hexane/dichloromethane (9/1; $6 \mathrm{ml})$ and dichloromethane $(6 \mathrm{ml})$. The extraction and cleanup procedures were automated using a Rapidtrace Automated SPE workstation (Zymark Corp., Hopkinton, MA, USA), and evaporation was performed using a heated vacuum evaporator (Rapidvap; Labconco Corp.,Kansas City, MO, USA).The samples were concentrated and octachloronaphthalene was added as a recovery standard.

\subsubsection{Instrumental measurements}

The extracts $(30 \mu \mathrm{l})$ were analysed on an Agilent 7890A gas chromatograph (Agilent Technologies, Böblingen, Germany) equipped with a triple quadrupole mass spectrometer, Quattro Micro GC (Waters Corporation, Manchester, UK). Separation was performed on a $30 \mathrm{~m}$ DB5-MS column ( $0.25 \mathrm{~mm}$ id and $0.25 \mu \mathrm{m}$ film thickness; J\&W, Folsom, USA) with a programmed-temperature vaporisation PTV injector in splitless mode. An injection volume of $1 \mu \mathrm{L}$ of the extract was injected using a PTV: Agilent 7683 Series, Agilent Technologies, Böblingen, Germany injector in splitless mode. An injection volume of $1 \mu \mathrm{l}$ of the extract was injected. The initial PTV temperatures were initially $70^{\circ} \mathrm{C}$ and increased by $120^{\circ} \mathrm{C} \mathrm{min}{ }^{-1}$ to a final temperature of $275^{\circ} \mathrm{C}$ that was held for $3 \mathrm{~min}$. The $\mathrm{GC}$ temperature programme 
consisted of an initial temperature of $70^{\circ} \mathrm{C}$ with a hold time of $3 \mathrm{~min}$; the temperature was then ramped at $15^{\circ} \mathrm{C} \mathrm{min}^{-1}$ to $180^{\circ} \mathrm{C}$, followed by a temperature ramp of $5^{\circ} \mathrm{C} \mathrm{min}^{-1}$ to $280^{\circ} \mathrm{C}$ with a hold time of $5 \mathrm{~min}$. Helium (6.0 quality, Hydrogas, Porsgrunn, Norway) was the carrier gas at $1 \mathrm{ml} \cdot \mathrm{min}^{-1}$ under constant flow conditions. The MS operated in MRM mode with an EI source set at $220^{\circ} \mathrm{C}$. Collision gas was argon at a pressure of approximately $2.3 \times 10-3$ mbar. Dwell times for specific ion transitions were 0.05 seconds. Information regarding specific transitions has been previously published in the literature (Pitarch et al., 2007). Peaks with differences in isotopic mass ratios greater than $20 \%$ compared to the quantification standard were rejected and not quantified.

\subsection{Quality assurance and quality control}

The accuracy of the analysis was assured through inclusion of certified reference materials and an internal QAQC pool in the analyses. The NILU laboratory participates in international inter-laboratory comparison programmes (AMAP Human Ringtest for plasma samples with $+/-20 \%$ deviation from result as best performance, according to AMAP Ringtest protocol).

The limits of detection (LODs) were calculated using the signal to noise ratio calculations in serum samples, and corresponded to 3 times the area of the noise or 3 times the average concentrations found in blank samples (28 samples).

The coefficient of variation was 13 and $12 \%$ within assays for $p, p^{\prime}-D D E$ and $p, p^{\prime}-D D T$, respectively, and $14 \%$ between assays for both metabolites in spiked bovine serum samples (30 spiked samples). Limits of detection for each compound measured are included in results tables.

\subsection{Total lipids enzymatic method}

Lipids were determined enzymatically and the total lipids were calculated according to a formula by Sandanger et al., (Sandanger et al., 2003).

\subsection{Questionnaire data}

Socio-economic, demographic, occupational activity, self-reported health status, diet and life style (smoking, alcohol consumption and leisure activities) data were obtained from each participant by interview. 
From delivery records, the researchers extracted following information: weight and length of the newborns, head circumference, Naegele term, Abgar score, gestational age, as well as congenital malformations, birth complications and outcomes as per comments of the doctor or sister present at delivery.

\subsection{Statistical analyses}

All data analyses were performed using STATA package, version 11 for Windows. (STATA 11.1, 2009) Descriptive statistics were calculated for socioeconomic and birth outcomes data. Given that the distributions of the concentration of the compounds measured were not normally distributed, the concentrations were log-transformed and geometric means were used for statistical analysis. The criteria of significance were set at a $p$ value of less than 0.05. The Spearman's Rank Correlation Coefficient Test for comparison for not normally distributed data were used, and the Kruskal-Wallis Rank Sum Test to compare the rank sum of means of more than two groups.

\subsection{Ethical considerations}

The study protocol was submitted to the Human Research Ethics Committee (Medical) of the University of the Witwatersrand and unconditional approval was obtained (Protocol: M040314). The study was also approved by the Provincial Health Research Committee, KwaZulu-Natal Department of Health (Reference: HRKM001/08).

\section{Results}

\subsection{Socio-economic, demographic and lifestyle characteristics}

Socioeconomic characteristics for participants in each study site are summarized in Table 1. Questionnaire data confirmed a similar socioeconomic status of participants at all sites. The majority of participants in the three sites were African Blacks and $2 \%$ in low risk and nonmalaria areas were of Asian origin. Participants in all three regions were South African citizens but in malaria region $1 \%$ reported to be foreigners. Zulu was the most spoken home language by $99 \%, 98 \%$ and $87 \%$ of women from malaria, low risk and non-malaria sites respectively. About $11 \%$ of women in non-malaria region spoke Xhosa and $2 \%$ in low risk and non-malaria spoke English. Majority of the women studied were not married but single. Secondary education was completed by $35 \%, 40 \%$ and $55 \%$; and $39 \%, 52 \%$ and $33 \%$ 
completed tertiary education by women from malaria, low risk and non-malaria sites, respectively. The differences in educational status of participants by site were statistically significant, with woman from the low risk area having higher tertiary education levels. Very few reported to be employed in all sites, reaching statistical significance between sites. They relied on social grants or the financial support of their partner and/or family members. Women reported not to smoke themselves, however about $46 \%$ in non- malaria, $30 \%$ in low risk malaria and $17 \%$ in malaria sites reported to have somebody smoking regularly in their homes.

The most common source of potable water was from the communal tap that was situated outside the houses. A number of participants from the malaria site also relied on either boreholes $(25 \%)$ or a river $(8 \%)$ as a source of drinking water; whereas in low risk and nonmalaria approximately $9 \%$ relied on a river as a source of drinking water. Participants tended not to move homes; mean number of years at the current residence or current address ranged between 16.7 and 18 years, with no significant differences between three study sites. Most of the participants lived in rural settings; highest (99\%) in the malaria area, followed by the non- malaria area $(90 \%)$ and low risk area $(68 \%)$, the differences were statistically significant. When asked about incidents of malaria in the past, $32 \%$ of women from the malaria site reported that they or a family member had contracted malaria in previous years, with highest incidents reported in years 1998, 1999 and in 2004.

Each subject was asked if their home was regularly sprayed by the Malaria Vector Control Programme and $96 \%$ in the malaria area answered yes. Intermittent spraying in the low risk site was reported by $20 \%$ of participants.

\subsection{Maternal data and birth outcomes by site}

The maternal data and the birth outcomes are summarised in Table 2. The mean age and mean weight of the mothers at delivery was not significantly different between sites. Mean body mass index (BMI) available only from malaria and non-malaria sites indicate that women from non-malaria site were significantly heavier with a BMI of 30(SD 9). Parity ranged between 0 and 8 , with $51 \%, 20 \%$ and $58 \%$ of mothers in the malaria site, low risk and non- malaria site, respectively, being nulliparous. The baby birth weight ranged from $1300 \mathrm{~g}$ to $5150 \mathrm{~g}$ with mean birth weights being significantly different across the three study sites. Low birth weight (LBW below $2500 \mathrm{~g}$ ) accounted for $6 \%, 6 \%$ and $11 \%$ of babies born in malaria, low risk and non-malaria sites, respectively. In most cases, the LBW was associated with gestational age and preterm emergency deliveries. Mean birth length and head circumference of newborns did not statistically differ between sites. There was a 
significant difference between the mean gestational age between the 3 sites, with lowest (37 weeks in non- malaria site) and the highest (39 weeks in low risk site). In all study sites majority of deliveries were vaginal. Highest number of caesarean deliveries (40\%) took place in the low risk malaria area, followed by the non- malaria site $(23 \%)$ and $15 \%$ in malaria site. In all sites, number of delivery complications and congenital malformations were also recorded at birth (see Table 2). Gender ratio was not similar at three sites ranging between 47 to $51 \%$ frequency for girls.

\subsection{DDT levels in maternal plasma at delivery}

Concentrations of DDT and metabolites in maternal blood plasma are summarized in Tables 3 and Table 4. For easy comparisons with non-lipid adjusted published data, Table 3 shows wet weight concentrations in $\mathrm{pg} / \mathrm{ml}$. For each site $\mathrm{GM}$, first and third quartile and LOD for each compound are presented. The limit of detection for $p, p^{\prime}$-DDT was $42 \mathrm{pg} / \mathrm{ml}$ and for p,p'-DDE was $71 \mathrm{pg} / \mathrm{ml}$. Percentages of results above LOD were $99 \%$ and $100 \%$ in the malaria region, $64 \%$ and $87 \%$ in low risk region and $3 \%$ and $80 \%$ and in non-malaria region, respectively.

Table 4 reports comparisons of lipid adjusted in $\mathrm{ng} / \mathrm{g}$ lipids by site. As expected, all the geometric mean concentrations of compounds measured were highest in the malaria area where IRS is taking place and the differences between sites were significant for all compounds $(p=0.0001)$. The concentrations of metabolites show large variation, especially in the malaria areas, with extreme outliers. At this site, three mothers had very high levels of $p, p^{\prime}$-DDE (above $45000 \mathrm{ng} / \mathrm{g}$ lipid) and p,p'-DDT (above $15000 \mathrm{ng} / \mathrm{g}$ lipid).

Of the metabolites measured, $p, p^{\prime}-\mathrm{DDE}$ was the most abundant. Geometric mean of $p, p^{\prime}-$ DDE in the malaria site was $3840 \mathrm{ng} / \mathrm{g}$ lipids, ranging from 37 to $92559 \mathrm{ng} / \mathrm{g}$ lipids. $p, p^{\prime}-\mathrm{DDE}$ was strongly and positively $(r>0.7)$ associated with $p, p^{\prime}$-DDT and $o, p^{\prime}$-DDT, and positively associated with the other metabolites but to a lesser extent ( $r$ range 0.3-0.5).

Similarly, levels of $p, p^{\prime}$-DDT were found to be highest in the malaria site with a median concentration of $2194 \mathrm{ng} / \mathrm{g}$ lipids, ranging from 8 to $21856 \mathrm{ng} / \mathrm{g}$ lipids. The median (range) concentration of its isomer $0, p^{\prime}-D D T$ was found to be 168(5-1744) ng/g lipids and showed little variation across individuals. For both the malaria endemic area and the low-risk area, $p, p^{\prime}$-DDE and $p, p^{\prime}$-DDT levels were highly correlated $(r>0.7)$, but not in the non-malarial site $(r=0.08)$. The body mass index and maternal age was negatively correlated with $p, p^{\prime}-\mathrm{DDT}$ and $p, p^{\prime}-D D E$ in the malaria area only $(r>0.4)$. 
The lowest geometric mean ratio $(95 \% \mathrm{Cl})$ for $p, p^{\prime}-\mathrm{DDE} / p, p^{\prime}-\mathrm{DDT}$ of $2(1.4-2.1)$ was found in the malaria endemic site, indicating recent exposure. Geometric mean ratios $(95 \% \mathrm{Cl})$ of $5(3.6-7.1)$ and $4(3.8-4.9)$ were found for the low-risk and non-malaria site, respectively, also indicating fairly recent exposure or fresh sources of exposure.

The relationship between some important maternal characteristics reported in the literature and the levels of $p, p^{\prime}$-DDE and $p, p^{\prime}$-DDT are shown in Table 5. Only $p, p^{\prime}-\mathrm{DDE}$ and $p, p^{\prime}-\mathrm{DDT}$ which are the main metabolites and most persistent, are presented. These compounds also had acceptable percentage $(90 \%)$ of results above LOD in the malaria area. Between the three study sites, age $(p=0.0064: p=0.0023)$, level of education $(p=0.0311 ; p=0.0029)$, permanent employment of the mothers $(p=0.0181 ; p=0.0059)$ and IRS spraying in the home $(p=0.0001 ; p=0.0001)$ were significant for both $p, p^{\prime}-D D E$ and $p, p^{\prime}-D D T$, respectively. In the malaria area age $(p=0.0016 ; p=0.0005)$, the number of children $(p=0.0108 ; p=0.0114)$, previous breastfeeding $(p=0.0490 ; p=0.0097)$ and IRS spraying $(0.0316 ; 0.0095)$ were significant for both $p, p^{\prime}$-DDE and $p, p^{\prime}$-DDT, respectively, and permanent employment of mothers $(p=0.0164)$ was significant for $p, p^{\prime}$-DDT only. IRS was associated with an increase in $p, p^{\prime}-\mathrm{DDE}$ and $p, p^{\prime}-\mathrm{DDT}$, whereas breastfeeding and higher levels of education were associated with a decrease in the pesticide concentrations.

\section{Discussion}

The use of DDT for IRS to control the malaria vector is a subject of intense debate among governmental parties, regulatory organisations, NGOs and scientists. Although numerous studies show the detrimental effects of DDT to humans and wildlife, there is limited research investigating an association between its controlled use for IRS and health. Prenatal exposure to these compounds is of particular concern.

Our study quantified the concentrations of DDTs and its metabolites in the blood plasma of delivering women to assess exposure in a malaria endemic IRS area and compared these results with low risk and non- malaria areas, all situated along the Indian Ocean coast of South Africa.

This study found that IRS with DDT for malaria vector control in malaria endemic region increases the concentrations of DDT and its metabolites in the blood plasma of delivering women. The levels of DDT and its metabolites were greatly elevated in this group with the $p, p^{\prime}$ - isomers being more abundant than $o, p^{\prime}$-isomers indicating significant prenatal 
exposure. Our findings also suggest that IRS may result in high DDT exposure in the general population. The study by Aneck-Hahn et al., 2007 on South African men residing in IRS houses found even higher concentrations of DDE in their blood (239 $\pm 215 \mu \mathrm{g} / \mathrm{g}$ lipid) (AneckHahn et al., 2007). Of concern, is also the fact that our study detected high levels of DDT in some of delivering women residing outside of the malaria endemic region along the coast of the KwaZulu Natal Province, who had no history of residing in an IRS region.

Highly elevated levels of $p, p^{\prime}-\mathrm{DDE}$ and $p, p^{\prime}-\mathrm{DDT}$ isomers measured in the plasma of delivering women in the IRS study site is of great concern. Bulk of the reported research identifies DDT and its metabolites as having multiple detrimental health effects of IRS on human health. However, data on levels of the exposure and health effects of IRS on pregnant women, neonates and young children and other susceptible population groups are still lacking. The study by Torres-Sanchez et al., 2007 on a perinatal cohort in Mexico reported on association between in utero exposure to $p, p^{\prime}-\mathrm{DDE}$ and neurodevelopment in infants during the first year of life at a concentration of $7.8 \mathrm{ng} / \mathrm{ml}$ in the $3^{\text {rd }}$ trimester, which is magnitudes lower than our results (Torres-Sanchez et al., 2007). They also identified the first trimester of the pregnancy to be a critical window of exposure to DDE. Recently, Eskenazi et al., 2009 reviewed 494 studies and concluded that there is a growing body of evidence that exposure to DDT and DDE may be associated with breast cancer, diabetes, decrease of semen quality and modulation of immune response. Some studies associate exposure to DDT with spontaneous abortions, short gestational length, low birth weight, short duration of lactation, urogenital birth defects and impaired neurodevelopment in children (Eskenazi et al., 2009). Thus, not all studies are consistent in their findings; concern is particularly evident in the relation to long term and chronic effects. This review also showed that recent studies of DDT/DDE levels in pregnant women and women of reproductive age differ by geographical regions.

The ratios of $p, p^{\prime}-\mathrm{DDE} / p, p^{\prime}-\mathrm{DDT}$ of 5 and 4 in the low-risk malaria area and non-malaria areas reflects continuous recent exposure, similar to the malaria area. These ratios cannot only be attributed to food source and further research is required to identify the source of exposure. The correlation between $p, p^{\prime}$-DDT and $p, p^{\prime}$-DDE indicate a similar source of exposure for high and low risk malarial sites, but not in the non-malarial site. The low ratios in the non-malaria and low risk areas suggest geographical dispersal of DDT.

The maternal characteristics where the overall $p$ value was significant, but not within each area, is due to the difference in the pesticide levels in the three sites that influences the results. The majority of the significant $p$-values for maternal characteristics were found in 
the malaria area, because the majority of exposure occurred in that area. The results have shown that the younger mothers had the highest DDT levels. This is partly influenced by the lack of previous breastfeeding for nulliparous women and/or fewer children, as breastfeeding reduces maternal levels as also shown by Lopez-Carillo et al., (Lopez-Carrillo et al., 2001). In the present study we found that both $p, p^{\prime}-\mathrm{DDE}$ and $p, p^{\prime}$-DDT metabolites were lowered by previous breastfeeding.

A high level of education in the low risk area was associated with lower concentration of $p, p^{\prime}-$ DDT. In addition, maternal permanent employment in the malaria area decreased $p, p^{\prime}-\mathrm{DDT}$ levels. This was not the same for $p, p^{\prime}-\mathrm{DDE}$, most likely because of the low number $(\mathrm{n}=4)$ of mothers employed and the fluctuation of the employment status in SA.

Research by Bornman et al., 2010 performed in Limpopo Province of South Africa (bordering to Zimbabwe) where IRS also takes place, found an association between DDE concentration in pregnant women and external urogenital birth defects, such as cryptorchidism, hypospadias, micropenis, and chlordee (Bornman et al., 2010).

Exposure to DDT and other pesticides during different stages of gestation is a subject of many studies worldwide. However, it is difficult to directly compare our results with those studies as a source of exposure in malaria areas is IRS with DDT (Wang et al., 2009; Weldon et al., 2010).

In 2006, we performed a pilot study in seven different regions of South Africa, with one site being the same malaria endemic site of the present study and measured the large spectrum of POPs. Concentrations of $p, p^{\prime}-\mathrm{DDE}$ and $p, p^{\prime}-\mathrm{DDT}$ were $5178 \mathrm{ng} / \mathrm{g}$ lipid and $1797 \mathrm{ng} / \mathrm{g}$ lipid respectively, which are similar to current results (Rollin et al., 2009) . Direct comparisons are not possible due to different sample sizes but cautiously we can state that 2006 results compared with the current study performed in 2008 indicate standardised procedures and consistent concentrations of DDT used for IRS.

Of concern is the persistency of DDT compounds in the environment, especially in soil and dust, foods and water but also its accumulation in human milk. Continuous intake of these contaminants is prolonged even after cessation of spraying through environmental contamination. Recent South African studies have reported on concentrations of DDT in breast milk, diet and environment in a region situated close to our current malaria site. Sereda et al reported mean sum of DDT in maternal breast milk fat (mf) of $10 \mu \mathrm{g} / \mathrm{g}$ ranging from 0.1 to $22 \mu \mathrm{g} / \mathrm{g} \mathrm{mf}$ (Sereda et al., 2009; Bouwman et al., 2006). These concentrations 
are higher than median concentrations of $0.80 \mu \mathrm{g} / \mathrm{g} \mathrm{mf}$ reported for $p, p^{\prime}-$ DDE by Ribas-Fitó et al., in milk of breastfeeding Spainish mothers (Ribas-Fito et al., 2005).

Another study by Van Dyk et al., 2010 performed in another IRS region of South Africa, namely Limpopo Province, found detectable levels of DDT in the indoor air, soil, floor dust, portable water, vegetables and chickens (Van Dyk et al., 2010).

Further research is required to establish health effects on the levels of exposure and possible means of reducing exposure in pregnant woman residing in IRS regions.

Most of the reported data on IRS and DDT concentration in humans are mainly associated with occupational exposure of male personnel directly engaged in spraying operations of the Malaria Control Programmes (Bimenya et al., 2010; Bouwman et al., 1991a; Bouwman et al., 1991b; Dalvie et al., 2004; de Jager et al., 2009).

In South Africa and bordering countries, a systematic program of insecticide resistance monitoring and surveillance, including collection of data on vector species and behaviour; ecology and transmission patterns (entomological inoculation rates) is taking place (Casimiro et al., 2006). This research is contributing to the understanding of vector changes and is communicated to malaria control programmes.

\section{Conclusions}

Findings of our study reaffirm the need for further research into the use of DDT and other insecticides to control malaria vector that are applied selectively at controlled doses to minimize the risks to the environment and the health of the population. Additional studies are also needed to further the understanding of potential health consequences to the foetus from DDT and other insecticides. Synergistic and additive risks of concomitant use of DDT with other alternatives and/or newer currently used insecticides need to be investigated as these are poorly defined. Furthermore, follow up studies of infant health and development in IRS regions should be initiated.

\section{ACKNOWLEDGMENTS}

The authors thank the Research Council of Norway and National Research Foundation, South Africa (Grant 64528), the Arctic Monitoring and Assessment Programme (AMAP), the Royal Norwegian Ministry for Foreign Affairs and the SA Medical Research Council for financial support. Support from the participants, relevant health departments, maternity 
sections and staff of hospitals is also acknowledged. We also thank colleagues from the SA Medical Research Council: Prof Piet Baker for overviewing of data input; Mrs Mirriam Mogotsi for her expert research assistance in data and sample collection. We also thank Mrs Kerry Downs, Department of Epidemiology, $\mathrm{NIOH}$, Johannesburg for statistical advice. Special thanks to Linda Hanssen and Charlotta Rylander from NILU for their invaluable analytical expertise and training.

Kalavati Channa is a PhD candidate at the Institute of Community Medicine, University of Tromsø, Norway.

\section{REFERENCES}

Alvarez-Pedrerol M, Ribas-Fito N, Torrent M, Carrizo D, Grimalt JO, Sunyer J. Effects of PCBs, p,p'$\mathrm{DDT}, \mathrm{p}, \mathrm{p}^{\prime}-\mathrm{DDE}, \mathrm{HCB}$ and beta-HCH on thyroid function in preschool children. Occup Environ Med 2008; 65: 452-7.

AMAP, 2004, Arctic Monitoring and Assessment Program. AMAP Assessment 2002: persistent organic pollutants in the Arctic., http://www.amap.no/, accessed 23 February2011.

Aneck-Hahn NH, Schulenburg GW, Bornman MS, Farias P, de Jager C. Impaired semen quality associated with environmental DDT exposure in young men living in a malaria area in the Limpopo Province, South Africa. J Androl 2007; 28: 423-34.

Arndt V, Vine MF, Weigle K. Environmental chemical exposures and risk of herpes zoster. Environ Health Perspect 1999; 107: 835-41.

Bimenya GS, Harabulema M, Okot JP, Francis O, Lugemwa M, Okwi AL. Plasma levels of DDT/DDE and liver function in malaria control personnel 6 months after indoor residual spraying with DDT in northern Uganda, 2008. S Afr Med J 2010; 100: 118-21.

Bornman R, de Jager C, Worku Z, Farias P, Reif S. DDT and urogenital malformations in newborn boys in a malarial area. BJU Int 2010; 106: 405-11.

Bouwman H, Cooppan RM, Becker PJ, Ngxongo S. Malaria control and levels of DDT in serum of two populations in Kwazulu. J Toxicol Environ Health 1991a; 33: 141-55.

Bouwman H, Cooppan RM, Botha MJ, Becker PJ. Serum levels of DDT and liver function of malaria control personnel. S Afr Med J 1991b; 79: 326-9.

Bouwman $\mathrm{H}$, Kylin $\mathrm{H}$. Malaria control insecticide residues in breast milk: the need to consider infant health risks. Environ Health Perspect 2009; 117: 1477-80.

Bouwman H, Sereda B, Meinhardt HM. Simultaneous presence of DDT and pyrethroid residues in human breast milk from a malaria endemic area in South Africa. Environ Pollut 2006; 144: 902-17.

Casimiro S, Coleman M, Hemingway J, Sharp B. Insecticide resistance in Anopheles arabiensis and Anopheles gambiae from Mozambique. J Med Entomol 2006; 43: 276-82.

Cohn BA, Wolff MS, Cirillo PM, Sholtz RI. DDT and breast cancer in young women: new data on the significance of age at exposure. Environ Health Perspect 2007; 115: 1406-14.

Dalvie MA, Myers JE, Lou Thompson M, Dyer S, Robins TG, Omar S, et al. The hormonal effects of long-term DDT exposure on malaria vector-control workers in Limpopo Province, South Africa. Environ Res 2004; 96: 9-19.

de Jager C, Aneck-Hahn NH, Bornman MS, Farias P, Leter G, Eleuteri P, et al. Sperm chromatin integrity in DDT-exposed young men living in a malaria area in the Limpopo Province, South Africa. Hum Reprod 2009; 24: 2429-38.

DOH, 2010, Department of Health, http://www.DoH.gov.za/facts/index.html, accessed 16 March2011. 
Eskenazi B, Chevrier J, Rosas LG, Anderson HA, Bornman MS, Bouwman H, et al. The Pine River statement: human health consequences of DDT use. Environ Health Perspect 2009; 117: 1359-67.

Eskenazi B, Marks AR, Bradman A, Fenster L, Johnson C, Barr DB, et al. In utero exposure to dichlorodiphenyltrichloroethane (DDT) and dichlorodiphenyldichloroethylene (DDE) and neurodevelopment among young Mexican American children. Pediatrics 2006; 118: 233-41.

Everett CJ, Frithsen IL, Diaz VA, Koopman RJ, Simpson WM, Jr., Mainous AG, 3rd. Association of a polychlorinated dibenzo-p-dioxin, a polychlorinated biphenyl, and DDT with diabetes in the 1999-2002 National Health and Nutrition Examination Survey. Environ Res 2007; 103: 413-8.

Fernandez MF, Olmos B, Granada A, Lopez-Espinosa MJ, Molina-Molina JM, Fernandez JM, et al. Human exposure to endocrine-disrupting chemicals and prenatal risk factors for cryptorchidism and hypospadias: a nested case-control study. Environ Health Perspect 2007; 115 Suppl 1: 8-14.

Jaga K, Dharmani C. Global surveillance of DDT and DDE levels in human tissues. Int J Occup Med Environ Health 2003; 16: 7-20.

Kapp C. New international convention allows use of DDT for malaria control. Bull World Health Organ 2004; 82: 472-3.

Lee DH, Lee IK, Song K, Steffes M, Toscano W, Baker BA, et al. A strong dose-response relation between serum concentrations of persistent organic pollutants and diabetes: results from the National Health and Examination Survey 1999-2002. Diabetes Care 2006; 29: 1638-44.

Longnecker MP, Gladen BC, Cupul-Uicab LA, Romano-Riquer SP, Weber JP, Chapin RE, et al. In utero exposure to the antiandrogen 1,1-dichloro-2,2-bis(p-chlorophenyl)ethylene (DDE) in relation to anogenital distance in male newborns from Chiapas, Mexico. Am J Epidemiol 2007; 165: 1015-22.

Lopez-Carrillo L, Torres-Sanchez L, Moline J, Ireland K, Wolff MS. Breast-feeding and serum p,p'DDT levels among Mexican women of childbearing age: a pilot study. Environ Res 2001; 87: 1315.

Nagayama J, Kohno H, Kunisue T, Kataoka K, Shimomura H, Tanabe S, et al. Concentrations of organochlorine pollutants in mothers who gave birth to neonates with congenital hypothyroidism. Chemosphere 2007; 68: 972-6.

Narita S, Goldblum RM, Watson CS, Brooks EG, Estes DM, Curran EM, et al. Environmental estrogens induce mast cell degranulation and enhance IgE-mediated release of allergic mediators. Environ Health Perspect 2007; 115: 48-52.

O'Meara WP, Mangeni JN, Steketee R, Greenwood B. Changes in the burden of malaria in subSaharan Africa. Lancet Infect Dis 2010; 10: 545-55.

Ostrea EM, Jr., Bielawski DM, Posecion NC, Jr., Corrion M, Villanueva-Uy E, Bernardo RC, et al. Combined analysis of prenatal (maternal hair and blood) and neonatal (infant hair, cord blood and meconium) matrices to detect fetal exposure to environmental pesticides. Environ Res 2009; 109: 116-22.

Pitarch E, Medina C, Portoles T, Lopez FJ, Hernandez F. Determination of priority organic micropollutants in water by gas chromatography coupled to triple quadrupole mass spectrometry. Anal Chim Acta 2007; 583: 246-58.

Porta M, Malats N, Jariod M, Grimalt JO, Rifa J, Carrato A, et al. Serum concentrations of organochlorine compounds and K-ras mutations in exocrine pancreatic cancer. PANKRAS II Study Group. Lancet 1999; 354: 2125-9.

Ribas-Fito N, Grimalt JO, Marco E, Sala M, Mazon C, Sunyer J. Breastfeeding and concentrations of HCB and p,p'-DDE at the age of 1 year. Environ Res 2005; 98: 8-13.

Ribas-Fito N, Torrent M, Carrizo D, Munoz-Ortiz L, Julvez J, Grimalt JO, et al. In utero exposure to background concentrations of DDT and cognitive functioning among preschoolers. Am J Epidemiol 2006; 164: 955-62. 
Rignell-Hydbom A, Rylander L, Hagmar L. Exposure to persistent organochlorine pollutants and type 2 diabetes mellitus. Hum Exp Toxicol 2007; 26: 447-52.

Rogan WJ, Chen A. Health risks and benefits of bis(4-chlorophenyl)-1,1,1-trichloroethane (DDT). Lancet 2005; 366: 763-73.

Rollin HB, Sandanger TM, Hansen L, Channa K, Odland JO. Concentration of selected persistent organic pollutants in blood from delivering women in South Africa. Sci Total Environ 2009; 408: 146-52.

Sagiv SK, Nugent JK, Brazelton TB, Choi AL, Tolbert PE, Altshul LM, et al. Prenatal organochlorine exposure and measures of behavior in infancy using the Neonatal Behavioral Assessment Scale (NBAS). Environ Health Perspect 2008; 116: 666-73.

Sandanger TM, Brustad M, Lund E, Burkow IC. Change in levels of persistent organic pollutants in human plasma after consumption of a traditional northern Norwegian fish dish-molje (cod, cod liver, cod liver oil and hard roe). J Environ Monit 2003; 5: 160-5.

Sandanger TM, Sinotte M, Dumas P, Marchand M, Sandau CD, Pereg D, et al. Plasma concentrations of selected organobromine compounds and polychlorinated biphenyls in postmenopausal women of Quebec, Canada. Environ Health Perspect 2007; 115: 1429-34.

Sapbamrer R, Prapamontol T, Prakobvitayakit O, Vaneesorn Y, Mangklabruks A, Hock B. Placental transfer of DDT in mother-infant pairs from Northern Thailand. J Environ Sci Health B 2008; 43: 484-9.

Schell LM, Gallo MV, Denham M, Ravenscroft J, DeCaprio AP, Carpenter DO. Relationship of thyroid hormone levels to levels of polychlorinated biphenyls, lead, p,p'- DDE, and other toxicants in Akwesasne Mohawk youth. Environ Health Perspect 2008; 116: 806-13.

Sereda, B.; Bouwman, H.; Kylin, H. Comparing water, bovine milk, and indoor residual spraying as possible sources of DDT and pyrethroid residues in breast milk. J Toxicol Environ Health 2009; A. 72, 842-851.

Sunyer J, Torrent M, Munoz-Ortiz L, Ribas-Fito N, Carrizo D, Grimalt J, et al. Prenatal dichlorodiphenyldichloroethylene (DDE) and asthma in children. Environ Health Perspect 2005; 113: 1787-90.

Torres-Sanchez L, Rothenberg SJ, Schnaas L, Cebrian ME, Osorio E, Del Carmen Hernandez M, et al. In utero $p, p^{\prime}-$ DDE exposure and infant neurodevelopment: a perinatal cohort in Mexico. Environ Health Perspect 2007; 115: 435-9.

UNEP, 2005, United Nations Environment Programme. Ridding the world of POPs: a guide to the Stockholm convention on persistent organic pollutants,, http://www.pops.int/documents/guidance/beg guide.pdf, accessed 6 September2011.

Van Dyk JC, Bouwman H, Barnhoorn IE, Bornman MS. DDT contamination from indoor residual spraying for malaria control. Sci Total Environ 2010; 408: 2745-52.

van Wendel de Joode B, Wesseling C, Kromhout H, Monge P, Garcia M, Mergler D. Chronic nervoussystem effects of long-term occupational exposure to DDT. Lancet 2001; 357: 1014-6.

Wang RY, Jain RB, Wolkin AF, Rubin CH, Needham LL. Serum concentrations of selected persistent organic pollutants in a sample of pregnant females and changes in their concentrations during gestation. Environ Health Perspect 2009; 117: 1244-9.

Weldon RH, Webster M, Harley KG, Bradman A, Fenster L, Davis MD, et al. Serum Persistent Organic Pollutants and Duration of Lactation among Mexican-American Women. J Environ Public Health 2010; 2010: 861757.

WHO, 2008, The Global Malaria Action Plan for a Malaria-free world, http://www.rollbackmalaria.org/gmap/index.html, accessed 02 March2011. 
Figure 1: Probable and confirmed malaria cases per year in South Africa 1990-2009 Source DOH, SA (DOH 2010)

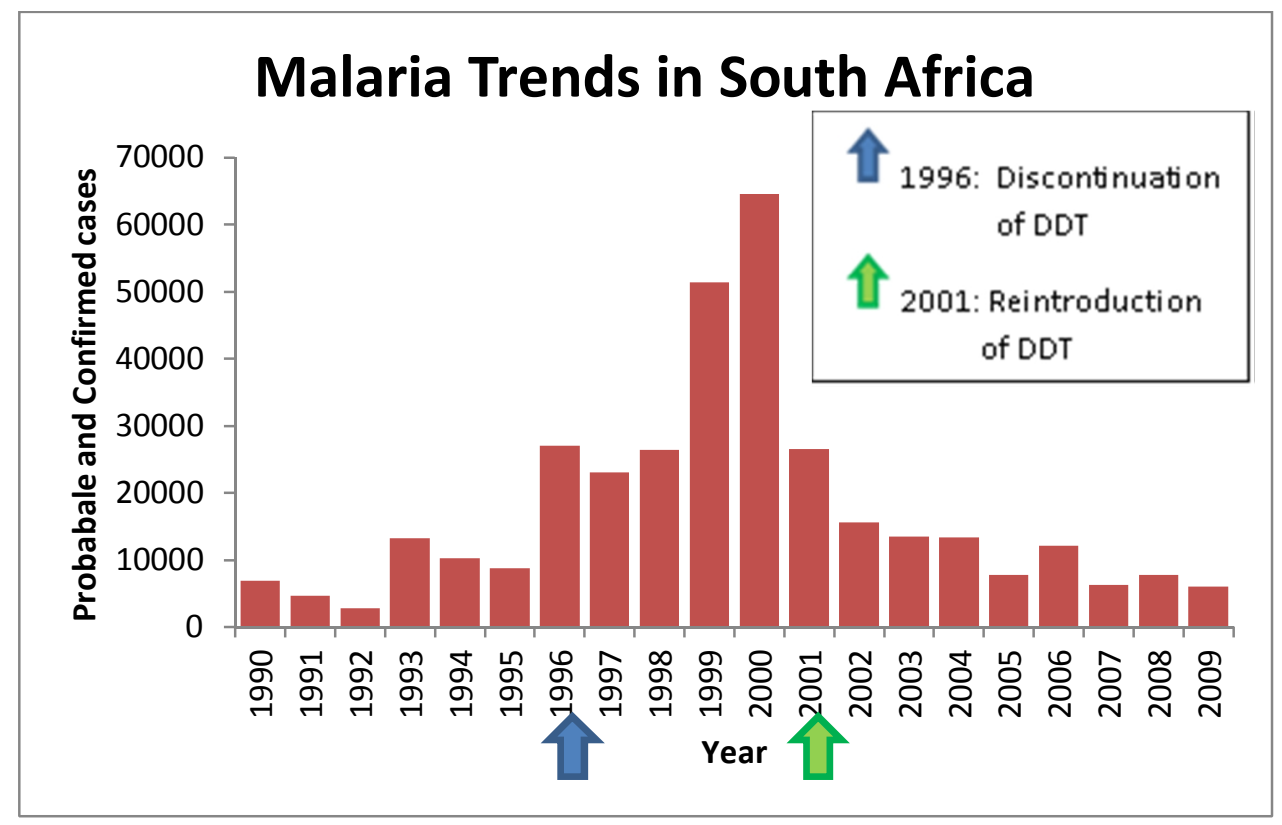


Figure 2: Geographical positions of study sites within KwaZulu- Natal, South Africa.

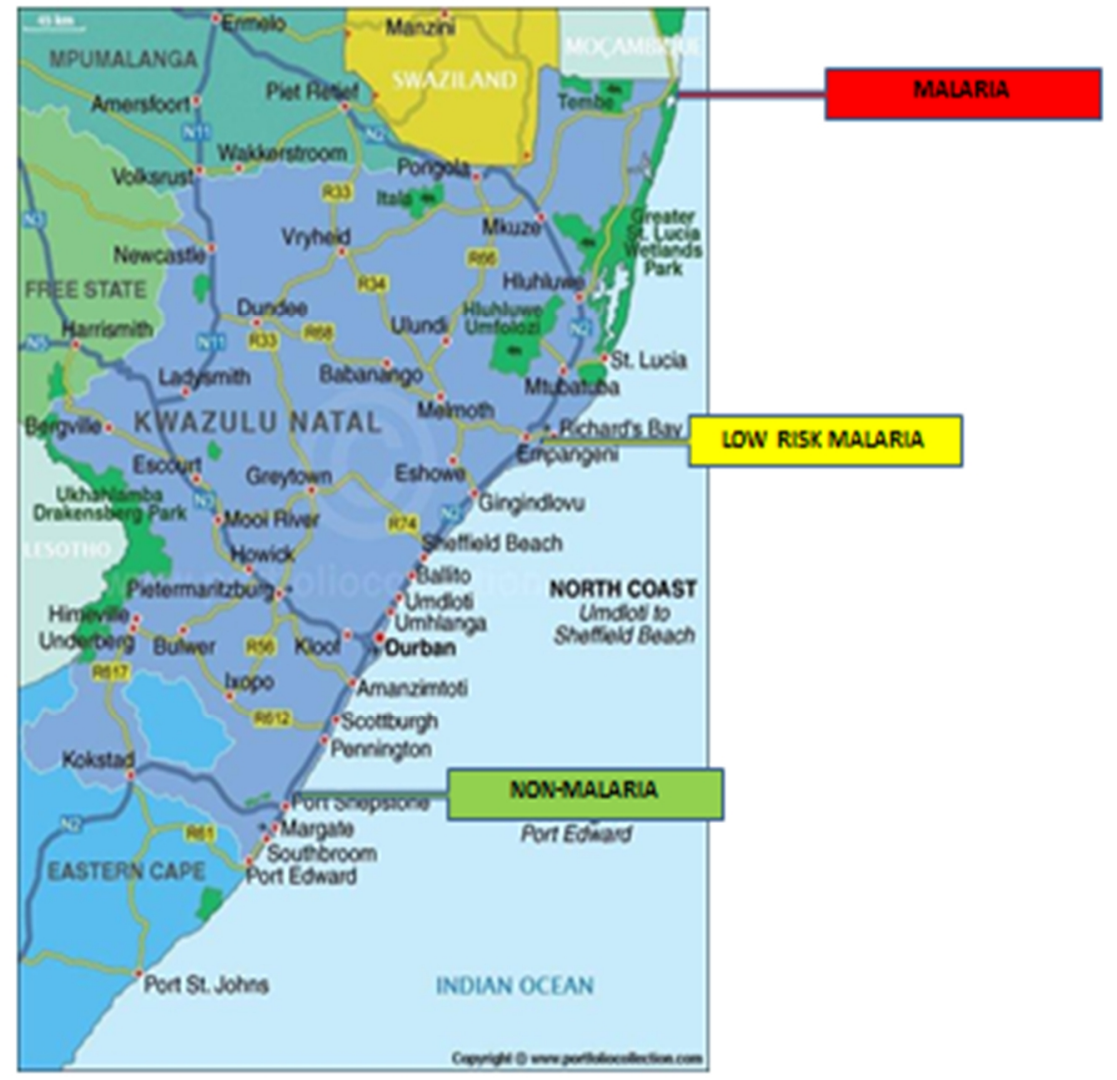


Table 1: Socioeconomic characteristic of participants by site

\begin{tabular}{|c|c|c|c|c|}
\hline & $\begin{array}{c}\text { Malaria } \\
\mathrm{n}=91\end{array}$ & $\begin{array}{c}\text { Low risk } \\
\mathrm{n}=47\end{array}$ & $\begin{array}{c}\text { Non-malaria } \\
n=117\end{array}$ & P value \\
\hline $\begin{array}{l}\text { Population group (\%) } \\
\text { B= Black } \\
\text { A= Asian }\end{array}$ & $\begin{array}{c}\text { B } 100 \\
-\end{array}$ & $\begin{array}{c}\text { B } 98 \\
\text { A } 2\end{array}$ & $\begin{array}{l}\text { B } 98 \\
\text { A } 2\end{array}$ & ns \\
\hline $\begin{array}{l}\text { Nationality (\%) } \\
\text { South African } \\
\text { Other }\end{array}$ & $\begin{array}{c}99 \\
1\end{array}$ & 100 & 100 & ns \\
\hline $\begin{array}{l}\text { Language (\%) } \\
\text { Zulu } \\
\text { Xhosa } \\
\text { English } \\
\text { Other }\end{array}$ & $\begin{array}{c}99 \\
- \\
- \\
1\end{array}$ & $\begin{array}{c}98 \\
- \\
2 \\
-\end{array}$ & $\begin{array}{c}87 \\
11 \\
2 \\
-\end{array}$ & $<0.05$ \\
\hline $\begin{array}{l}\text { Marital Status (\%) } \\
\text { Married } \\
\text { Single } \\
\text { Living together } \\
\text { Widowed }\end{array}$ & $\begin{array}{c}5 \\
62 \\
33 \\
-\end{array}$ & $\begin{array}{c}13 \\
85 \\
2 \\
-\end{array}$ & $\begin{array}{c}16 \\
76 \\
7 \\
1\end{array}$ & $<0.05$ \\
\hline $\begin{array}{l}\text { Maternal education (\%) } \\
\text { Primary school } \\
\text { Secondary school } \\
\text { Tertiary }\end{array}$ & $\begin{array}{l}26 \\
35 \\
39\end{array}$ & $\begin{array}{c}8 \\
40 \\
52\end{array}$ & $\begin{array}{l}11 \\
55 \\
33\end{array}$ & $<0.05$ \\
\hline $\begin{array}{l}\text { Employment mothers (\%) } \\
\text { Yes }\end{array}$ & 4 & 11 & 16 & $<0.05$ \\
\hline Somebody smoking at home (\%) & 17 & 30 & 46 & $<0.05$ \\
\hline $\begin{array}{l}\text { Drinking water source (\%) } \\
\text { Indoor Tap } \\
\text { Outdoor Tap } \\
\text { Rainwater } \\
\text { Borehole } \\
\text { River }\end{array}$ & $\begin{array}{c}3 \\
60 \\
2 \\
25 \\
8\end{array}$ & $\begin{array}{c}20 \\
62 \\
6 \\
2 \\
10\end{array}$ & $\begin{array}{c}14 \\
78 \\
0 \\
0 \\
8\end{array}$ & $<0.05$ \\
\hline $\begin{array}{l}\text { Length of residence at current home } \\
\text { Years (SD) }\end{array}$ & $18.0(9.7)$ & $17.0(11.0)$ & $16.7(9.7)$ & ns \\
\hline $\begin{array}{l}\text { Place of residence (\%) } \\
\text { Urban } \\
\text { Rural } \\
\text { Peri-urban } \\
\text { Others }\end{array}$ & $\begin{array}{c}0 \\
99 \\
1 \\
0\end{array}$ & $\begin{array}{c}4 \\
68 \\
21 \\
7\end{array}$ & $\begin{array}{c}6 \\
90 \\
4 \\
0\end{array}$ & $<0.05$ \\
\hline
\end{tabular}


Table 2: Maternal data and birth outcomes

\begin{tabular}{|c|c|c|c|c|}
\hline & $\begin{array}{c}\text { Malaria } \\
n=91\end{array}$ & $\begin{array}{c}\text { Low risk } \\
\mathrm{n}=47\end{array}$ & $\begin{array}{c}\text { Non-malaria } \\
n=117\end{array}$ & $P$ value \\
\hline $\begin{array}{l}\text { Maternal mean age } \\
\text { Years (SD*) } \\
\text { Range }\end{array}$ & $\begin{array}{c}24(7) \\
(14-42)\end{array}$ & $\begin{array}{c}25(6) \\
(15-45)\end{array}$ & $\begin{array}{c}24(5) \\
(16-37)\end{array}$ & ns \\
\hline $\begin{array}{l}\text { Maternal weight prior to delivery } \\
\text { Mean } \mathrm{Kg} \text { (SD) }\end{array}$ & $71(11)$ & 74(13) & $76(13)$ & ns \\
\hline $\begin{array}{l}\text { BMI } \\
\text { Mean at delivery }\left(\mathrm{kg} / \mathrm{m}^{2}\right)\end{array}$ & $24(4)$ & Not available & $30(9)$ & $<0.05$ \\
\hline $\begin{array}{l}\text { Parity mean (SD) } \\
\text { Range }\end{array}$ & $\begin{array}{c}1.0(1.5) \\
(0-6)\end{array}$ & $\begin{array}{l}1.2(1.6) \\
(0-8)\end{array}$ & $\begin{array}{l}0.8(1.0) \\
(0-5)\end{array}$ & $<0.05$ \\
\hline $\begin{array}{l}\text { Birth weight }(g) \\
\text { Mean (SD) } \\
\text { Range } \\
\text { Underweight }(\%) \leq 2500 \text { g }\end{array}$ & $\begin{array}{c}3147(464) \\
2100-4250 \\
6\end{array}$ & $\begin{array}{c}3250(426) \\
2300-4400 \\
6\end{array}$ & $\begin{array}{c}2990(531) \\
1300-5150 \\
11\end{array}$ & $<0.05$ \\
\hline $\begin{array}{l}\text { Birth length }(\mathrm{cm}) \\
\text { Mean (SD) }\end{array}$ & 49(3) & $50(2)$ & $49(3)$ & ns \\
\hline $\begin{array}{l}\text { Head circumference }(\mathrm{cm}) \\
\text { Mean (SD) }\end{array}$ & $35(1)$ & $35(2)$ & $35(2)$ & ns \\
\hline $\begin{array}{l}\text { Gestation age (weeks) } \\
\text { Mean (SD) }\end{array}$ & $38(2)$ & 39(1) & $37(2)$ & $<0.05$ \\
\hline $\begin{array}{l}\text { Delivery mode (\%) } \\
\text { Vaginal } \\
\text { Caesarean section }\end{array}$ & $\begin{array}{l}85 \\
15\end{array}$ & $\begin{array}{l}60 \\
40\end{array}$ & $\begin{array}{l}77 \\
23\end{array}$ & \\
\hline Gender (\%) girls & 49 & 47 & 51 & \\
\hline Maternal delivery complications & death 1 & $\begin{array}{l}\text { postpartum } 1 \\
\text { haemorrhage } 1 \\
\text { asphyxia } 1 \\
\text { epilepsy } 1 \\
\text { anaemia } 2\end{array}$ & $\begin{array}{l}\text { placenta retention } 2 \\
\text { hypertension } 11 \\
\text { preterm } 2 \\
\text { preeclampsia } 1 \\
\text { anaemia } 2 \\
\text { epilepsy } 1 \\
\text { tumour } 1\end{array}$ & \\
\hline $\begin{array}{l}\text { Congenital malformations } \\
\text { detected at birth }\end{array}$ & none & Down Syndrome 1 & $\begin{array}{l}\text { hand or foot extra } \\
\text { digits } 3\end{array}$ & \\
\hline
\end{tabular}

*SD = standard deviation 
Table 3: DDT metabolites in maternal plasma at delivery $(\mathrm{pg} / \mathrm{ml})$ by site

\begin{tabular}{|c|c|c|c|c|}
\hline Compounds & Statistics & $\begin{array}{c}\text { Malaria } \\
\mathrm{N}=91\end{array}$ & $\begin{array}{c}\text { Low Risk } \\
\mathrm{N}=47\end{array}$ & $\begin{array}{c}\text { Non-malaria } \\
\quad \mathrm{N}=117\end{array}$ \\
\hline$o, p^{\prime}-\mathrm{DDE}$ & $\begin{array}{l}\mathrm{GM}^{\mathrm{a}} \\
\text { Median } \\
\text { Range } \\
\text { IQR }^{\mathrm{b}} \\
\text { LOD }^{\mathrm{c}} \\
\% \text { detected }>\mathrm{LOD}\end{array}$ & $\begin{array}{c}47 \\
35 \\
35-1105 \\
35-52 \\
35 \\
27\end{array}$ & $\begin{array}{c}36 \\
35 \\
35-94 \\
35-35 \\
35 \\
2\end{array}$ & 0 \\
\hline$p, p^{\prime}-\mathrm{DDE}$ & $\begin{array}{l}\text { GM } \\
\text { Median } \\
\text { Range } \\
\text { IQR } \\
\text { LOD } \\
\% \text { detected >LOD }\end{array}$ & $\begin{array}{c}20279 \\
22613 \\
290-444782 \\
11217-37523 \\
71 \\
100\end{array}$ & $\begin{array}{c}1167 \\
1064 \\
71-24889 \\
372-5661 \\
71 \\
87\end{array}$ & $\begin{array}{c}189 \\
179 \\
70-2783 \\
113-315 \\
71 \\
80\end{array}$ \\
\hline$o, p^{\prime}-\mathrm{DDD}$ & $\begin{array}{l}\text { GM } \\
\text { Median } \\
\text { Range } \\
\text { IQR } \\
\text { LOD } \\
\% \text { detected }>\text { LOD }\end{array}$ & $\begin{array}{c}41 \\
28 \\
28-3149 \\
28-47 \\
28 \\
33\end{array}$ & $\begin{array}{c}29 \\
28 \\
28-102 \\
28-28 \\
28 \\
4\end{array}$ & 0 \\
\hline$p, p^{\prime}$-DDD & $\begin{array}{l}\text { GM } \\
\text { Median } \\
\text { Range } \\
\text { IQR } \\
\text { LOD } \\
\% \text { detected }>\text { LOD }\end{array}$ & $\begin{array}{c}137 \\
150 \\
42-1478 \\
42-370 \\
42 \\
66\end{array}$ & $\begin{array}{c}57 \\
42 \\
42-583 \\
42-43 \\
42 \\
15\end{array}$ & 0 \\
\hline$o, p^{\prime}$-DDT & $\begin{array}{l}\text { GM } \\
\text { Median } \\
\text { Range } \\
\text { IQR } \\
\text { LOD } \\
\% \text { detected }>\text { LOD }\end{array}$ & $\begin{array}{c}851 \\
1287 \\
35-11186 \\
652-2062 \\
35 \\
87\end{array}$ & $\begin{array}{c}35 \\
35 \\
35-2127 \\
35-35 \\
35 \\
21\end{array}$ & 0 \\
\hline$p, p^{\prime}-\mathrm{DDT}$ & $\begin{array}{l}\text { GM } \\
\text { Median } \\
\text { Range } \\
\text { IQR } \\
\text { LOD } \\
\% \text { detected }>\text { LOD }\end{array}$ & $\begin{array}{c}11841 \\
13666 \\
42-110271 \\
7951-23668 \\
42 \\
99\end{array}$ & $\begin{array}{c}227 \\
123 \\
42-13260 \\
42-1093 \\
42 \\
64\end{array}$ & $\begin{array}{c}44 \\
42 \\
42-280 \\
42-42 \\
42 \\
3\end{array}$ \\
\hline
\end{tabular}

a geometric mean

${ }^{\mathrm{b}}$ inter-quartile range

c limit of detection 
Table 4: Lipid corrected (ng/g lipid) of DDT and metabolites in mothers at delivery at the three sites

\begin{tabular}{|c|c|c|c|c|}
\hline Compounds & Statistics & $\begin{array}{c}\text { Malaria } \\
\mathrm{N}=91\end{array}$ & $\begin{array}{l}\text { Low Risk } \\
\qquad \mathrm{N}=47\end{array}$ & $\begin{array}{c}\text { Non-malaria } \\
\mathrm{N}=117\end{array}$ \\
\hline$o, p^{\prime}-\mathrm{DDE}$ & $\begin{array}{l}\mathrm{GM}^{\mathrm{a}}(95 \% \mathrm{Cl}) \\
\text { Median } \\
\text { Range } \\
\mathrm{IQR}^{\mathrm{b}}\end{array}$ & $\begin{array}{c}9(7-10) \\
7 \\
4-172 \\
6-7\end{array}$ & $\begin{array}{c}6(5-6) \\
6 \\
4-25 \\
5-6\end{array}$ & $\begin{array}{c}5(5-6) \\
6 \\
3-8 \\
5-6\end{array}$ \\
\hline$p, p^{\prime}-\mathrm{DDE}$ & $\begin{array}{l}\text { GM }(95 \% \mathrm{Cl}) \\
\text { Median } \\
\text { Range } \\
\text { IQR }\end{array}$ & $\begin{array}{c}3840(3008-4902) \\
4092 \\
37-92559 \\
1986-7341\end{array}$ & $\begin{array}{c}191(116-315) \\
184 \\
11-4739 \\
54-908\end{array}$ & $\begin{array}{c}29(25-33) \\
26 \\
8-343 \\
18-49\end{array}$ \\
\hline$o, p^{\prime}-\mathrm{DDD}$ & $\begin{array}{l}\text { GM }(95 \% \mathrm{Cl}) \\
\text { Median } \\
\text { Range } \\
\text { IQR }\end{array}$ & $\begin{array}{c}8(6-9) \\
6 \\
3-456 \\
5-10\end{array}$ & $\begin{array}{c}5(4-5) \\
4 \\
3-20 \\
4-5\end{array}$ & $\begin{array}{c}4(4-5) \\
4 \\
2-7 \\
4-5\end{array}$ \\
\hline$p, p^{\prime}-\mathrm{DDD}$ & $\begin{array}{l}\text { GM }(95 \% \mathrm{CI}) \\
\text { Median } \\
\text { Range } \\
\text { IQR }\end{array}$ & $\begin{array}{c}26(20-32) \\
26 \\
5-230 \\
8-66\end{array}$ & $\begin{array}{c}9(7-11) \\
7 \\
5-111 \\
6-8\end{array}$ & $\begin{array}{c}7(6-7) \\
7 \\
4-10 \\
6-8\end{array}$ \\
\hline$o, p-{ }^{\prime} \mathrm{DDT}$ & $\begin{array}{l}\text { GM }(95 \% \mathrm{CI}) \\
\text { Median } \\
\text { Range } \\
\text { IQR }\end{array}$ & $\begin{array}{c}168(127-221) \\
226 \\
5-1744 \\
108-376\end{array}$ & $\begin{array}{c}9(7-12) \\
6 \\
4-405 \\
5-8.5\end{array}$ & $\begin{array}{c}5(5-6) \\
6 \\
3-8 \\
5-6\end{array}$ \\
\hline$p, p^{\prime}$-DDT & $\begin{array}{l}\text { GM }(95 \% \mathrm{Cl}) \\
\text { Median } \\
\text { Range } \\
\text { IQR }\end{array}$ & $\begin{array}{c}2194(1706-2823) \\
2788 \\
8-21856 \\
1279-4525\end{array}$ & $\begin{array}{c}38(22-65) \\
27 \\
5-2425 \\
7-165\end{array}$ & $\begin{array}{c}7(6-7) \\
7 \\
4-37 \\
6-8\end{array}$ \\
\hline
\end{tabular}

${ }^{\mathrm{a}}$ geometric mean

${ }^{\mathrm{b}}$ inter-quartile range

For all the DDT metabolites $p=0.0001$ between the three areas. 
Table 5: Relationship between maternal characteristics and $p, p^{\prime}-\mathrm{DDE}$ and $p, p^{\prime}$-DDT concentrations (ng/g lipids) by study site

\begin{tabular}{|c|c|c|c|c|c|c|c|c|c|c|c|c|c|c|}
\hline $\begin{array}{l}\text { Maternal } \\
\text { characteristics }\end{array}$ & \multicolumn{7}{|c|}{$\begin{array}{c}p, p^{\prime}- \\
\text { DDE } \\
\text { GM } \\
(95 \% \mathrm{Cl}) \\
\end{array}$} & \multicolumn{7}{|c|}{$\begin{array}{c}p, p^{\prime}-\mathrm{DDT} \\
\mathrm{GM}(95 \% \mathrm{Cl})\end{array}$} \\
\hline $\begin{array}{l}\text { Number of } \\
\text { subjects }(n)\end{array}$ & $\mathrm{n}$ & Malaria & $\mathrm{n}$ & Low risk & $n$ & $\begin{array}{l}\text { Non- } \\
\text { malaria }\end{array}$ & $\begin{array}{c}\text { P- } \\
\text { value } \\
\text { overall }\end{array}$ & $\mathrm{n}$ & Malaria & $\mathrm{n}$ & Low risk & $n$ & $\begin{array}{l}\text { Non- } \\
\text { malaria }\end{array}$ & $\begin{array}{c}P \text { - } \\
\text { value } \\
\text { overall }\end{array}$ \\
\hline $\begin{array}{l}\text { Age (years) } \\
\leq 20 \\
20-29 \\
\geq 30 \\
P \text {-value }\end{array}$ & $\begin{array}{l}31 \\
39\end{array}$ & $\begin{array}{l}6638(4948- \\
8904) \\
2862(1872- \\
4374) \\
2957(1773- \\
4930) \\
0.0016 \\
\end{array}$ & $\begin{array}{l}8 \\
26 \\
13\end{array}$ & $\begin{array}{l}508(90- \\
2874) \\
167(95- \\
296) \\
138(44- \\
432) \\
0.2013 \\
\end{array}$ & $\begin{array}{l}28 \\
66 \\
18\end{array}$ & $\begin{array}{c}31(22- \\
43) \\
27(23- \\
32) \\
35(25- \\
49) \\
0.3614 \\
\end{array}$ & 0.0064 & $\begin{array}{l}31 \\
39\end{array}$ & $\begin{array}{l}4075(3147- \\
5276) \\
1682(1077- \\
2626) \\
1442(851- \\
2443) \\
0.0005\end{array}$ & $\begin{array}{l}8 \\
26 \\
13\end{array}$ & 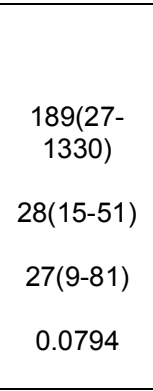 & $\begin{array}{l}28 \\
66 \\
18\end{array}$ & $\begin{array}{l}7(6-8) \\
7(6-7) \\
7(6-8) \\
0.3476\end{array}$ & 0.0023 \\
\hline $\begin{array}{l}\text { Level of } \\
\text { Education } \\
\text { Primary } \\
\text { school } \\
\text { Secondary } \\
\text { school } \\
\text { Tertiary } \\
\text { P-value }\end{array}$ & $\begin{array}{l}21 \\
29 \\
30\end{array}$ & $\begin{array}{l}5425(3026- \\
9725) \\
4860(3456- \\
6834) \\
3007(1859- \\
4864) \\
0.2690 \\
\end{array}$ & $\begin{array}{l}4 \\
19 \\
24\end{array}$ & $\begin{array}{l}247(7- \\
9018) \\
294(127- \\
677) \\
131(68- \\
252) \\
0.2795 \\
\end{array}$ & $\begin{array}{l}12 \\
61 \\
36\end{array}$ & $\begin{array}{l}29(17- \\
48) \\
32(27- \\
38) \\
28(21- \\
36) \\
0.6117 \\
\end{array}$ & 0.0311 & $\begin{array}{l}21 \\
29 \\
30\end{array}$ & $\begin{array}{l}2838(1803- \\
4467) \\
2551(1471- \\
4425) \\
1571(988- \\
2499) \\
0.0684 \\
\end{array}$ & $\begin{array}{l}4 \\
19 \\
24\end{array}$ & $\begin{array}{c}80(1-5690) \\
95(39-232) \\
16(9-29) \\
0.0049\end{array}$ & $\begin{array}{l}12 \\
61 \\
36\end{array}$ & $\begin{array}{l}8(6-9) \\
7(6-7) \\
7(6-7) \\
0.3905\end{array}$ & 0.0029 \\
\hline $\begin{array}{l}\text { Employment } \\
\text { mothers } \\
\text { Yes } \\
\text { No } \\
\text { P-value }\end{array}$ & $\begin{array}{l}4 \\
87\end{array}$ & 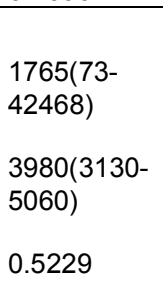 & $\begin{array}{l}5 \\
42\end{array}$ & $\begin{array}{l}417(64- \\
2723) \\
174(102- \\
297) \\
0.2848\end{array}$ & $\begin{array}{l}18 \\
93\end{array}$ & $\begin{array}{l}26(19- \\
35) \\
30(26- \\
36) \\
0.5274\end{array}$ & 0.0181 & $\begin{array}{l}4 \\
87\end{array}$ & $\begin{array}{l}482(29- \\
8089) \\
2353(1843- \\
3003) \\
0.0164\end{array}$ & $\begin{array}{l}5 \\
42\end{array}$ & $\begin{array}{l}55(6-466) \\
36(20-66) \\
0.4478\end{array}$ & $\begin{array}{l}18 \\
93\end{array}$ & $\begin{array}{l}6(6-7) \\
7(6-7) \\
0.3873\end{array}$ & 0.0059 \\
\hline $\begin{array}{l}\text { IRS Spraying } \\
\text { Yes } \\
\text { No } \\
\text { P-value }\end{array}$ & $\begin{array}{l}87 \\
4\end{array}$ & $\begin{array}{l}4117(3249- \\
5218) \\
845(64- \\
11099) \\
0.0316\end{array}$ & $\begin{array}{l}9 \\
37\end{array}$ & $\begin{array}{l}319(83- \\
1230) \\
162(92- \\
283) \\
0.2505\end{array}$ & $\begin{array}{l}1 \\
111\end{array}$ & $\begin{array}{l}13^{*} \\
30(26- \\
34) \\
0.2218\end{array}$ & 0.0001 & $\begin{array}{l}87 \\
4\end{array}$ & $\begin{array}{l}2406(1898- \\
3049) \\
297(20- \\
4398) \\
0.0095\end{array}$ & $\begin{array}{l}9 \\
37\end{array}$ & $\begin{array}{l}60(12-307) \\
34(18-63) \\
0.4547\end{array}$ & $\begin{array}{l}1 \\
111\end{array}$ & $\begin{array}{c}8^{*} \\
7(6-7) \\
0.2587\end{array}$ & 0.0001 \\
\hline 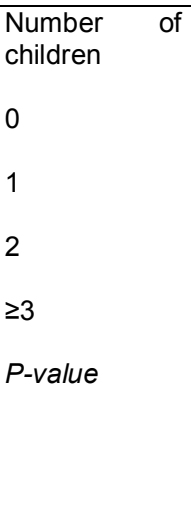 & $\begin{array}{l}50 \\
19 \\
8 \\
12\end{array}$ & $\begin{array}{l}4960(3546- \\
6937) \\
3256(1916- \\
5535) \\
2021(1231- \\
3319) \\
2204(978- \\
4966) \\
0.0108\end{array}$ & $\begin{array}{l}21 \\
10 \\
8 \\
8\end{array}$ & $\begin{array}{l}311(146- \\
664) \\
98(30- \\
315) \\
214(52- \\
888) \\
110(26- \\
463) \\
0.2671\end{array}$ & $\begin{array}{l}58 \\
32 \\
13 \\
8\end{array}$ & $\begin{array}{l}31(26- \\
39) \\
25(20- \\
33) \\
29(19- \\
44) \\
28(14- \\
57) \\
0.6004\end{array}$ & 0.1256 & $\begin{array}{l}50 \\
19 \\
8 \\
12\end{array}$ & $\begin{array}{l}2787(1933- \\
4017) \\
1631(1011- \\
2632) \\
1451(839- \\
2509) \\
1484(620- \\
3551) \\
0.0114\end{array}$ & $\begin{array}{l}21 \\
10 \\
8 \\
8\end{array}$ & $\begin{array}{l}49(19-127) \\
26(8-87) \\
60(10-343) \\
20(8-52) \\
0.7261\end{array}$ & $\begin{array}{l}58 \\
32 \\
13 \\
8\end{array}$ & $\begin{array}{l}7(6-7) \\
7(6-7) \\
6(5-7) \\
7(5-10) \\
0.8905\end{array}$ & 0.2770 \\
\hline $\begin{array}{l}\text { Cumulative } \\
\text { Breastfeeding } \\
\text { Never } \\
\text { 1-48 months }\end{array}$ & $\begin{array}{l}55 \\
36\end{array}$ & $\begin{array}{l}\text { 4415(3110- } \\
6266) \\
3103(2264-\end{array}$ & $\begin{array}{l}23 \\
24\end{array}$ & $\begin{array}{l}281(139- \\
569) \\
132(64-\end{array}$ & $\begin{array}{l}72 \\
45\end{array}$ & $\begin{array}{l}31(26- \\
37) \\
26(21-\end{array}$ & 0.2319 & $\begin{array}{l}55 \\
36\end{array}$ & $\begin{array}{l}\text { 2544(1758- } \\
3682) \\
\text { 1751(1296- }\end{array}$ & $\begin{array}{l}23 \\
24\end{array}$ & $\begin{array}{l}43(18-104) \\
34(17-70)\end{array}$ & $\begin{array}{l}72 \\
45\end{array}$ & $\begin{array}{l}7(6-7) \\
7(6-7)\end{array}$ & 0.5300 \\
\hline
\end{tabular}




\begin{tabular}{|l|l|l|l|l|l|l|l|l|l|l|l|l|l|}
\hline P-value & $\begin{array}{l}4254) \\
0.0490\end{array}$ & & $\begin{array}{l}273) \\
0.1363\end{array}$ & & $\begin{array}{l}32) \\
0.2439\end{array}$ & & & $\begin{array}{l}2366) \\
0.0097\end{array}$ & & 0.3521 & & \\
\hline
\end{tabular}

* =only 1 observation in this group. 